\title{
Book Review: How Creating Customer Value Makes You a Great Executive by Gautam Mahajan
}

\author{
B.S. Galdolage
}

University of Sri Jayewardenepura

The history of value perceptions in marketing goes back to the end of the 19th century, to the industrial revolution which gave rise to 'transaction marketing'. It made a dichotomy between the customer and producer, making value one-way directional from the provider to the customer. In the early 1990s, many 'industrial nations' which were recognised as 'production-led economies' started transforming into 'service led' seeking to establish long-term relationships with customers focusing on customer retention more than attracting new customers. However, value creation in the third millennium, progressively transformed into a new stage giving priority to the collaborative perspective of value creation which termed as cocreation.

Today, we are in the 21st century, which also known as the 'experience economy' where the key focus of business organisation is to provide superior customer value and memorable experiences. Thus, customer value becomes the key in today's competitive business environment. If a business organization can provide such an impressive and exceptional customer value, it can be the pioneers in the market by touching the consumer hearts and minds well.

If an author explains these transitions of value concept and its significance to the todays business world and try to open ears and eyes of the businesses to be witnessed the miracles happen when they provide what customers value, he is none other than, Gautam Mahajan, a top expert in creating customer value. 
$\mathrm{He}$ is the author of series of books written on value creation such as 'Customer Value Investment: Formula for Sustained Business success', 'Total Customer Value Management: Transforming Business Thinking and Value Creation' as well as 'Value Creation: The Definitive Guide for Business Leaders'. This book, 'How creating customer value makes you a great executive' also such a special gift bestowed by the author to readers who enjoy customer value journey.

This book consists with sixteen chapters which have logically connected each other. The first chapter, 'What is and how to use value' tells the reader how simple actions of businesses cause creating or destroying customer value. It advises businesses to know customers' DNA (Do Not Annoy) to become successful while reducing customer defects. Next chapters suggest using 'customer water fall of needs' and 'attribute trees' to understand the customer value when mapping the customer's journey. Further it explains how to measure 'Customer Value Added' (CVA) which is a comparative score developed using market data. Further, author advises business organizations to compare themselves with others, not just with the own business organization, with the aim of achieving pre-empt strategies.

In the chapter seven and eight, author links customer 'value' and 'loyalty' saying "small changes in value can have a large impact on loyalty". The importance of using 'loyalty curves' and 'value maps' to visually realize the organization's competitive position in the marketplace in terms of value provision is discussed in the book. Broader view of value creation aiming at customers, partners, employees and society was explained as the vehicle of creating incomparable value to the whole eco-system and to the company in return.

In chapter nine, Total Customer Value Management is viewed as the focus of everybody within the organization, which founded on building a customer culture which gives great competitive advantages. Importance of building 'a circle of promise' which secures customer's trust was well explained in the chapter ten as the foundation of zero complaint programs.

As discussed in the chapter eleven, in a customer culture, customer comes first, and create circles (customer circle) which consists with self-directed and self- learning groups of people. They provoke shared vision and teamwork where people work together being a pillar of a successful learning organization. Thus, business organizations should create such a customer culture and empower them to become opinion leaders who provide insights to the organization to be competitive as well as recommend the organization to peers through positive word of mouth communication. 
Chapter twelve justifies the importance of Customer's 'bill of right' which explains customer's rights when they are dealing with the organization. Now adays customers are aware, informed, and knowledgeable on their rights. Since businesses are also working towards continuous customer improvement programs, they should empower their customers by providing bill of rights when dealing with the organization.

Remaining chapters explain the importance of ensuring value to the customer through treating employees as assets. Therefore, to become a customer expert, a manager, business owner or an employee should shift from being a functional manager to a value creator who creates value to the entire eco system. Additionally, 'learning from others', also grow into a better predictor of the future of a successful business organization.

In a period where 'value' become the prime concern in every business, the contribution done by the author Gautam Mahajan to the entire business world and academia is invaluable. As a researcher in Value and Value co-creation, I was fortunate to present one of my papers at the First Global Conference on Creating Value held in DE Montfort University, United Kingdom in 2018 and awarded this valuable book from Gautam Mahajan who is the founding editor of the journal of creating value and chairmen of the customer value foundation. Now it is the turn of the value creators to read and reflect to make the world a better future. 